\title{
No Reason Given
}

National Cancer Institute

\section{Source}

National Cancer Institute. No Reason Given. NCI Thesaurus. Code C106487.

There was no excuse provided. 